\title{
Associates of Comprehensive HIV/AIDS Knowledge and Acceptance Attitude among Male Youth Aged 15-24: Comparison Study among Ivory Coast, Cameroon and Gabon
}

\section{Minet $\mathrm{TH}^{1}$, Eyasu $\mathrm{HT}^{2 *}$, Simon $\mathrm{AG}^{3}$, Afewerki $\mathrm{WT}^{3}$, Henok $\mathrm{KA}^{4}$ and Russom $\mathrm{T}^{5}$}

${ }^{1}$ School of Nursing, Tongji Medical College, Huazhong University of Science and Technology, Wuhan, China

${ }^{2}$ School of Public Health, Asmara College of Health Sciences, Asmara, Eritrea

${ }^{3}$ School of Public Health, Tongji Medical College, Huazhong University of Science and Technology, Wuhan, China

${ }^{4}$ Department of Pathology and Pathophysiology, Tongji Medical College, Huazhong University of Science and Technology, Wuhan, China

${ }^{5}$ School of Nursing, Asmara College of Health Sciences, Asmara, Eritrea

\begin{abstract}
Background: Ivory Coast, Cameroon and Gabon are the highly HIVIAIDS prevalent West African countries. However, studies show that nationally representative or comparative studies had never been done. Hence, this study was focused on associates of comprehensive HIVIAIDS knowledge and acceptance attitude towards people living with HIVIAIDS (PLHA) among male youth of the three countries and comparison by country.

Method: We utilized nationally representative datasets from Demographic and Health Surveys (DHS) of Ivory Coast 2011/2012, Cameroon 2011 and Gabon 2012. A total of 6576 male youth; 1811 (27.5\%) Ivorian, 2803 (42.6\%) Cameroonian and $1962(29.8 \%)$ Gabonese was taken. We used IBM SPSS version 22 to run multivariate logistic regression taking $p$-values less than 0.05 as significant.

Results: The comprehensive knowledge of HIVIAIDS and acceptance attitude towards PLHA in all the three countries were low; especially knowledge in Ivory Coast $(39.1 \%)$ and attitude in Gabon $(22.5 \%)$ were very low. On multivariate analysis, only age, residence, educational level, and wealth index were significant associates of comprehensive HIVIAIDS knowledge. On the other hand, age, religion, educational level, and wealth index were significant associates of acceptance attitude towards PLHA. On comparison, Gabonese (AOR=1.50, $p<0.001)$ and Cameroonians (AOR=1.44, $p<0.001)$ were more likely to have comprehensive HIVIAIDS knowledge than Ivorians. However, Ivorians were $1.18(\mathrm{AOR}=0.85, p=0.032)$ and Cameroonians were1.26 (AOR=1.26, $p=0.001)$ times more likely to have acceptance attitude than Gabonese.
\end{abstract}

Conclusion: Comprehensive HIVIAIDS knowledge and acceptance attitude towards PLHA in the three countries and specifically, acceptance attitude in Gabon was considerably low. Hence, it is crucial to give emphasis on planning policy of transmitting information to youth in a contextually applicable to the socio-cultural differences.

Keywords: Male youth; Comprehensive knowledge; Acceptance attitude; HIV/AIDS; Ivory Coast; Cameroon; Gabon

\section{Introduction}

Globally, total estimate of HIV infected people was 36.9 million, out of which 25.8 million were living in sub-Saharan Africa, in 2014 [1]. The epidemics in West Africa accounted for 6.6 million [5.9 million-7.5 million] people living with HIV. Despite the annual number of people newly infected by HIV has dropped from 3.1 million to 2.0 million in the last 15 years globally, the HIV epidemic in Western Africa has shown unwavering pattern and even an increment in some countries [2,3]. The prevalence of HIV/AIDS has increased from $4.3 \%$ in 2011 to $4.8 \%$ in 2014 in Cameroon, the first highly exposed West African country [4,5]. The prevalence stood at around 4.0\% (4.1\% in 2012 and $3.9 \%$ in 2014) in Gabon which is the second highly exposed country $[6,7]$. The third highly HIV prevalent country, Ivory Coast has also shown a small reduction in prevalence from $2011 / 12$ to 2014 (3.7\% to $3.5 \%)[8,9]$.

The Joint United Nations Program on HIV/AIDS (UNAIDS) has set the next five years, 2016 to 2020 , as a fragile window of opportunity to fast-track the AIDS response and empower people to lead dignified and rewarding lives. Gabon has been identified as a country that requires focused action. Cameroon and Ivory Coast are also among the 35 identified fast-track countries that account for more than $90 \%$ of people acquiring HIV infection and $90 \%$ of people dying from AIDS- related causes worldwide in which special focus and accelerated efforts are needed.

The third target of the strategic milestone for 2020 regarding HIV/ AIDS is to empower $90 \%$ of young people, regardless of where they live or who they are, with knowledge, skills, services, rights and power to protect themselves from HIV [2]. This is because of the fact that young people aged 15-24 are particularly vulnerable due to quick physical and psychosocial development in the history of HIV. Empirically, $42 \%$ of the new HIV infections in 2010 accounted for young people out of which $80 \%$ were living in sub-Saharan Africa [10]. A study done in Gabon indicated that youth have inadequate information about HIV/ AIDS transmission and prevention in which only $55.7 \%$ were aware of

*Corresponding author: Eyasu Habte Tesfamariam, Department of Epidemiology and biostatistics, School of Public Health, Asmara College of Health Sciences, Asmara, Eritrea, Tel: 002917471477; E-mail: yohoshua79@yahoo.com

Received August 27, 2016; Accepted September 15, 2016; Published September 22, 2016

Citation: Minet TH, Eyasu HT, Simon AG, Afewerki WT, Henok KA, et al. (2016) Associates of Comprehensive HIVIAIDS Knowledge and Acceptance Attitude among Male Youth Aged 15-24: Comparison Study among Ivory Coast, Cameroon and Gabon. J AIDS Clin Res 7: 618. doi:10.4172/2155-6113.1000618

Copyright: ( 2016 Minet TH, et al. This is an open-access article distributed unde the terms of the Creative Commons Attribution License, which permits unrestricted use, distribution, and reproduction in any medium, provided the original author and source are credited. 
Citation: Minet TH, Eyasu HT, Simon AG, Afewerki WT, Henok KA, et al. (2016) Associates of Comprehensive HIV/AIDS Knowledge and Acceptance Attitude among Male Youth Aged 15-24: Comparison Study among Ivory Coast, Cameroon and Gabon. J AIDS Clin Res 7: 618. doi:10.4172/2155-6113.1000618

Page 2 of 8

HIV transmission through sexual intercourse and only $25.62 \%$ of youth were used condoms while engaging in sexual activities [11]. Similarly, studies revealed that male youth have more risk sexual behaviors than female youth [12].

High levels of knowledge of HIV transmission and prevention, and acceptance attitude towards PLHA have been well noted as crucial pre-requisite for creating HIV/AIDS free generation [13,14]. After well consideration of this concept, the UNAIDS has well noted that conducting research on epidemiology, HIV-related stigma and service delivery as one of the eight main roles of civil society in order to achieve 2030 ambition [2]. On the other hand, literature review has revealed that there is little information available on the epidemiology of HIV in western Africa with a special focus on men. There could be two main reasons for why men were understudied in the context of knowledge and attitude towards HIV/AIDS in the previous research studies. The first one was the special priority given to the disproportionately affected young women, seconded by focus in men who have sex with men. Though priorities to the highly affected ones is important, men in general should also not be neglected or understudied for they have direct contribution on the epidemics of young women, and on the other hand the focused men who have sex with men are also bifurcated out of them.

Even though information regarding HIV/AIDS related knowledge has been reported by a number of researchers, there still exists gap due to limited available data in different sub-Saharan countries which of course embraces the selected three countries [15]. On the other hand, low knowledge, less acceptance attitude towards PLHA and high risk sexual behaviors were observed in small scale studies done in Gabon and Cameroon [11,16-19]. The lower level of acceptance attitude has resulted in high cases of denial and refusal among people infected to disclose their HIV/AIDS status [20]. Other gaps and challenges identified among Central and West African countries were poor sexand age-disaggregated epidemiological and programmatic national and subnational data, especially on the key young and adolescent populations [2].

Therefore, the purpose of this study was to present an epidemiological study that could transparently alleviate the gap by answering two research questions. 1) Which variables are associates of comprehensive HIV/AIDS knowledge and acceptance attitude? 2) How does the comparison of the level of comprehensive knowledge in HIV/ AIDS and acceptance attitude towards PLHA look like among 15-24 aged male youth of the three countries? To our knowledge, this is the first study that compared comprehensive HIV/AIDS knowledge and acceptance attitude towards PLHA among male youth aged 15-24 of the three countries.

\section{Method}

\section{Data source}

The analysis in this research was based on data collected from the most recent Demographic and Health Survey (DHS) in Cameroon (2011), Gabon (2012) and Ivory Coast (2011/2012) [21]. The currently utilized data were mainly restricted to male of age group 15-24 only. The fact that probability proportionate to size was used in selecting the samples and defining the dependent variables based on the MEASURE DHS online tools for HIV/AIDS Survey Indicators Database of the three countries were two advantages of the data [22]. This helped to offer representative, an internationally-accepted and consistent method for measuring factors related to HIV prevention across countries.

\section{Measures}

\section{Dependent variables}

The first dependent variable, comprehensive HIV/AIDS knowledge, was defined as (1) knowing that both condom use and limiting sex partners to one uninfected faithful partner are HIV prevention methods, (2) being aware that a healthy looking person can have the AIDS virus, and (3) rejecting at least two out of the three most common local misconceptions-that the AIDS virus can be transmitted through mosquito bites, a person can get HIV by sharing meal with someone infected, and by supernatural means. Comprehensive HIV/AIDS knowledge was a binary response variable coded 1 if youth reported five correct responses and 0 otherwise. In order to assess acceptance attitude towards PLHA, respondents were asked if they would (1) be willing to care for their relative sick with the AIDS virus in their own households, (2) be willing to buy fresh vegetables from a market vendor who had the AIDS virus, (3) say that a female teacher who has the AIDS virus but is not sick should be allowed to continue teaching, and (4) not want to keep a family member's HIV positive status secret [22]. Acceptance attitude towards PLHA was coded 1 if youth correctly answered the four questions and 0 otherwise.

\section{Independent variables}

The independent variables taken from the survey were age, level of education, place of residence, marital status, religion, wealth index and occupation. The first two age groups viz., 15-19 and 20-24, from the seven 5 year groups created in DHS data were utilized. Place of residence was taken without any change as urban and rural. The four levels of education were: no education, primary education, secondary education, and higher education. The six categories of marital status were: never married, married, living together, widowed, and divorced and not living together. Religion was re-categorized in such a way as to fit in to four categories. The first group was Christian (Catholic, Protestant, Methodist, Evangelical and Other Christians), seconded by Muslim and then followed by other religion (Animist and other religions) and finally no religion. DHS grouped wealth index as poorest, poorer, middle, richer, and richest, was taken to compare the influence of wealth on the dependent variables. Occupation was also regrouped into four classifications: agricultural (self-employed and employee), sales, services and others (services, professional/technical/managerial, clerical, household and domestic, skilled/unskilled manpower, armed force, others) and not working.

\section{Statistical Analysis}

Descriptive statistics were used to summarize the demographic characteristics, knowledge and acceptance attitude about HIV/AIDS. Binary logistic regressions were performed to establish whether there were relationships between independent variables and HIV knowledge levels and acceptance attitude towards PLHA. Because our dependent variables, comprehensive knowledge and acceptance attitude, were dichotomous and mutually exclusive variables. Similarly, comparisons among the countries were also done using logistic regression. For binary multivariate analyses, we calculated adjusted odds ratios (OR) at $95 \%$ confidence interval (CI) by taking $p$-value $<0.05$ as statistically significant. Missed cases were not included throughout the analysis. PASW (SPSS version 22) statistical software was used for data analysis.

\section{Results}

\section{Background characteristics}

Table 1 presents the distribution of male aged $15-24$ by 
Citation: Minet TH, Eyasu HT, Simon AG, Afewerki WT, Henok KA, et al. (2016) Associates of Comprehensive HIV/AIDS Knowledge and Acceptance Attitude among Male Youth Aged 15-24: Comparison Study among Ivory Coast, Cameroon and Gabon. J AIDS Clin Res 7: 618. doi:10.4172/2155-6113.1000618

Page 3 of 8

\begin{tabular}{|c|c|c|c|c|}
\hline \multirow{3}{*}{\multicolumn{2}{|c|}{ Variables }} & \multirow{3}{*}{$\begin{array}{c}\text { Ivory Coast } \\
\mathrm{N}=1811 \\
\mathrm{~N}(\%)\end{array}$} & \multirow{3}{*}{$\begin{array}{c}\text { Cameroon } \\
\begin{array}{c}\mathrm{N}=2803 \\
\mathrm{~N}(\%)\end{array}\end{array}$} & \multirow{3}{*}{$\begin{array}{c}\text { Gabon } \\
\begin{array}{c}\mathrm{N}=1962 \\
\mathrm{~N}(\%)\end{array}\end{array}$} \\
\hline & & & & \\
\hline & & & & \\
\hline & $15-20$ & $924(51.0)$ & $1612(57.5)$ & $1192(60.8)$ \\
\hline & $20-24$ & $887(49.0)$ & $1191(42.5)$ & $770(39.2)$ \\
\hline \multicolumn{5}{|c|}{ Type of residence } \\
\hline & Urban & 939 (51.8) & $1561(55.7)$ & $1403(71.5)$ \\
\hline & Rural & $872(48.2)$ & $1242(44.3)$ & $559(28.5)$ \\
\hline \multicolumn{5}{|c|}{ Educational status } \\
\hline & No education & $492(27.2)$ & $134(4.8)$ & $44(2.2)$ \\
\hline & Primary & $486(26.8)$ & $754(26.9)$ & $492(25.1)$ \\
\hline & secondary & $780(43.1)$ & $1770(63.1)$ & $1389(70.8)$ \\
\hline & Higher & $53(2.9)$ & $145(5.1)$ & $37(1.9)$ \\
\hline \multicolumn{5}{|c|}{ Religion $†$} \\
\hline & Christian & $646(35.7)$ & $2066(74.5)$ & $1459(74.4)$ \\
\hline & Muslim & $791(43.8)$ & $570(20.6)$ & $97(4.9)$ \\
\hline & Other religion & $125(6.9)$ & $28(1.0)$ & $24(1.2)$ \\
\hline & No religion & $245(13.6)$ & $108(3.9)$ & $381(19.4)$ \\
\hline \multicolumn{5}{|c|}{ Marital status } \\
\hline & Never in union & $1651(91.2)$ & $2511(89.6)$ & $1752(89.3)$ \\
\hline & Married & $61(3.4)$ & $112(4)$ & $14(0.7)$ \\
\hline & Living with partner & $79(4.4)$ & $149(5.3)$ & $160(8.2)$ \\
\hline & Divorced & $1(0.1)$ & $5(0.2)$ & - \\
\hline & No longer living together & $19(1)$ & $26(0.9)$ & $36(1.8)$ \\
\hline \multicolumn{5}{|c|}{ Wealth index } \\
\hline & Poorest & $297(16.4)$ & $368(13.1)$ & $681(34.7)$ \\
\hline & poorer & $311(17.2)$ & $471(16.8)$ & $494(25.2)$ \\
\hline & Middle & $367(20.3)$ & $584(20.8)$ & $281(14.3)$ \\
\hline & Richer & $389(21.5)$ & $679(24.2)$ & $253(12.9)$ \\
\hline & Richest & $447(24.7)$ & $701(25.0)$ & $253(12.9)$ \\
\hline \multicolumn{5}{|c|}{ Occupationft } \\
\hline & Not Working & $648(35.8$ & $875(31.2)$ & $1091(55.6)$ \\
\hline & Agriculture & $545(30.1)$ & $802(28.6)$ & $145(7.4)$ \\
\hline & Sales & $92(5.1)$ & $290(10.3)$ & $80(4.1)$ \\
\hline & Services and Others & $526(29.0)$ & $836(29.8)$ & $646(32.9)$ \\
\hline \multicolumn{5}{|c|}{ HIVIAIDS Awareness } \\
\hline & Yes & $1726(95.4)$ & $2729(97.4)$ & $1929(98.3)$ \\
\hline & No & $84(4.6)$ & $74(2.6)$ & $33(1.7)$ \\
\hline \multicolumn{5}{|c|}{ Comprehensive Knowledge } \\
\hline & Yes & $671(39.1)$ & $1308(48.1)$ & $941(49.0)$ \\
\hline & No & $1044(60.9)$ & $1412(51.9)$ & $979(51.0)$ \\
\hline \multicolumn{5}{|c|}{ Acceptance Attitude } \\
\hline & Yes & $440(25.6)$ & $732(26.8)$ & $434(22.5)$ \\
\hline & No & $1281(74.4)$ & $1997(73.2)$ & $1493(77.5)$ \\
\hline
\end{tabular}

†Religion and ††occupation were re-categorized

Table 1: Distribution of socio-demographic characteristics, HIVIAIDS awareness comprehensive HIVIAIDA knowledge, and acceptance attitude towards PLHA of males 15-24 years old in the three countries.

background characteristics. The information on age, education, place of residence, marital status, employment, and wealth status are useful for understanding the factors that affect comprehensive HIV/AIDS knowledge and acceptance attitudes towards PLHA. Of the 6576 male youth respondents taken from the survey, 1811 (27.5\%) were from Ivory Coast, 2803 (42.6\%) from Cameroon and 1962 (29.8\%) from Gabon. Differences by age group in the three countries varied slightly, in which the percentage of male youth with in the age group of $15-19$ was $51.0 \%$ in Ivory Coast, $57.5 \%$ in Cameroon and $60.8 \%$ in Gabon. Although no marked differences of residence in Ivorian and Cameroonian youth were seen, Gabonese offers a dissimilar picture. Almost half of the male youth in Ivory Coast (51.8\%) and Cameroon (55.7\%) were living in urban while the majority was observed in Gabon (71.5\%).

Some educational differentials were observed in the three countries among male youth. There was a wide variation in proportion of youth with no education with the highest in Ivory Coast (27.2\%) followed by Cameroon $(4.8 \%)$ and Gabon $(2.2 \%)$. The predominant educational level among male youth in Ivory Coast (43.1\%), Cameroon (63.1\%) and Gabon $(70.8 \%)$ was the secondary level. The percentage of youth having higher educational level was $2.9 \%$ in Ivory Coast, $5.1 \%$ in Cameroon and $1.9 \%$ in Gabon. The major religion among male youth in Ivory Coast (43.8\%) was Muslim. However, majority of the male youth in Cameroon (74.5\%) and Gabon (74.4\%) were Christians. Considerable proportion of no religion also existed in Gabon (19.4\%).

Regarding marital status, majority of male youth in Ivory Coast (91.2\%), Cameroon (89.6\%) and Gabon (89.3\%) had been never in union. The proportion of male youth living with partner in Ivory Coast (4.4\%) and Cameroon (5.3\%) were similar but slightly higher in Gabon $(8.2 \%)$. The proportion of male youth increased with an increase in wealth index in Ivory Coast and Cameroon. However, the reverse was observed in Gabon in which the poorest accounted highest proportion (34.7\%) of youth and then declined with increase in wealth index. The predominant part of male youth in Ivory Coast (35.8\%), Cameroon (31.2\%) and Gabon (55.6\%) had no occupation. Agriculture, in Ivory Coast (30.1\%), services and others in Cameroon (29.8\%) and Gabon (32.9\%) were the second more dominant areas of occupation for the youth.

Generally, the awareness of male youth in the three countries was universal in which $95.4 \%$ of Ivorians, $97.4 \%$ Cameroonians and $98.3 \%$ of Gabonese have heard about HIV/AIDS. The comprehensive knowledge of HIV/AIDS of males in Gabon, Cameroon and Ivory Coast were $49 \%, 48 \%$ and $39.1 \%$, respectively. Acceptance attitude towards PLHA among male youth in descending order was Cameroon (26.8\%), Ivory Coast (25.6\%) and Gabon (22.5\%).

\section{Comprehensive knowledge of male youth}

The comprehensive knowledge of youth against socio-demographic associates is presented in Table 2. Males aged 20-24 from Ivory Coast $(\mathrm{AOR}=1.44, p<0.001)$, Cameroon $(\mathrm{AOR}=1.54, p<0.001)$, and Gabon ( $\mathrm{AOR}=1.30, p=0.018$ ) were more likely to have comprehensive HIV/ AIDS knowledge compared to those aged 15-19. Significantly higher comprehensive knowledge of HIV/AIDS was observed in Gabon $(\mathrm{AOR}=1.35, \mathrm{p}=0.017)$ among males living in urban than those in rural. However, urban residents did not show significant comprehensive knowledge difference than rural, in Ivory Coast and Cameroon.

As the educational level of the males increases their corresponding comprehensive knowledge about HIV/AIDS also had increased. In Ivory Coast, males with primary $(\mathrm{AOR}=2.21, \mathrm{p}<0.001)$, secondary $(\mathrm{AOR}=5.74, \mathrm{p}<0.001)$ and higher $(\mathrm{AOR}=10.78, \mathrm{p}<0.001)$ educational level had more comprehensive knowledge than those with no education. More comprehensive knowledge on HIV/AIDS was also found in primary $(\mathrm{AOR}=2.10, \mathrm{p}=0.008)$, secondary $(\mathrm{AOR}=6.57, \mathrm{p}<0.001)$ and higher $(\mathrm{AOR}=9.13, \mathrm{p}<0.001)$ educational level than with no education in Cameroon. In Gabon, except males in primary, those in secondary $(\mathrm{AOR}=5.16, \mathrm{p}<0.001)$ and higher $(\mathrm{AOR}=8.22, \mathrm{p}<0.001)$ educational level had more comprehensive knowledge of HIV/AIDS than males with no education. 
Citation: Minet TH, Eyasu HT, Simon AG, Afewerki WT, Henok KA, et al. (2016) Associates of Comprehensive HIV/AIDS Knowledge and Acceptance Attitude among Male Youth Aged 15-24: Comparison Study among Ivory Coast, Cameroon and Gabon. J AIDS Clin Res 7: 618. doi:10.4172/2155-6113.1000618

Page 4 of 8

\begin{tabular}{|c|c|c|c|c|c|c|c|c|c|}
\hline \multirow[t]{2}{*}{ Variable } & \multicolumn{3}{|c|}{ Ivory Coast } & \multicolumn{3}{|c|}{ Cameroon } & \multicolumn{3}{|c|}{ Gabon } \\
\hline & OR & $95 \% \mathrm{Cl}$ & $P$ & OR & $95 \% \mathrm{Cl}$ & $P$ & OR & $95 \% \mathrm{Cl}$ & $\boldsymbol{P}$ \\
\hline \multicolumn{10}{|l|}{ Age (Ref=15-19) } \\
\hline $20-24$ & 1.44 & $1.21-1.73$ & $<0.001$ & 1.54 & $1.29-1.85$ & $<0.001$ & 1.30 & $1.05-1.61$ & 0.018 \\
\hline \multicolumn{10}{|l|}{ Place of Residence (Ref=Rural) } \\
\hline Urban & 1.30 & $0.9-1.87$ & 0.160 & 1.04 & $0.82-1.31$ & 0.770 & 1.35 & $1.06-1.74$ & 0.017 \\
\hline \multicolumn{10}{|c|}{ Highest Education level (Ref=No Education) } \\
\hline Primary & 2.12 & $1.5-2.99$ & $<0.001$ & 2.10 & $1.21-3.63$ & 0.008 & 1.87 & $0.79-4.41$ & 0.152 \\
\hline Secondary & 5.74 & $4.01-8.21$ & $<0.001$ & 6.57 & $3.83-11.27$ & $<0.001$ & 5.16 & $2.24-11.89$ & $<0.001$ \\
\hline Higher & 10.78 & $5.15-22.58$ & $<0.001$ & 9.13 & $4.71-17.68$ & $<0.001$ & 8.22 & $2.69-25.17$ & $<0.001$ \\
\hline \multicolumn{10}{|l|}{ Religion† (Ref=No religion) } \\
\hline Christian & 1.49 & $1.04-2.13$ & 0.031 & 1.28 & $0.82-1.99$ & 0.273 & 0.98 & $0.77-1.26$ & 0.892 \\
\hline Muslim & 1.38 & $0.96-1.99$ & 0.083 & 1.47 & $0.71-3.04$ & 0.303 & 1.70 & $0.98-2.92$ & 0.057 \\
\hline Other religion & 1.06 & $0.62-1.82$ & 0.822 & - & - & - & 0.55 & $0.21-1.41$ & 0.210 \\
\hline \multicolumn{10}{|l|}{ Marital Status (Ref=Never in Union) } \\
\hline Married & 0.69 & $0.33-1.42$ & 0.311 & 0.87 & $0.56-1.35$ & 0.526 & 2.03 & $0.64-6.4$ & 0.227 \\
\hline Living with partner & 1.14 & $0.66-1.96$ & 0.648 & 0.63 & $0.43-0.9$ & 0.011 & 0.85 & $0.59-1.22$ & 0.382 \\
\hline Divorced & - & - & - & 0.79 & $0.08-7.27$ & 0.832 & - & - & - \\
\hline No longer living together/separated & 1.28 & $0.46-3.53$ & 0.635 & 1.29 & $0.55-3.02$ & 0.556 & 0.58 & $0.27-1.21$ & 0.146 \\
\hline \multicolumn{10}{|l|}{ Wealth Index (Ref=Poorest) } \\
\hline Poorer & 1.42 & $0.94-2.16$ & 0.098 & 1.11 & $0.8-1.53$ & 0.534 & 1.27 & $0.97-1.66$ & 0.083 \\
\hline Middle & 1.17 & $0.74-1.85$ & 0.505 & 1.11 & $0.79-1.55$ & 0.540 & 1.07 & $0.78-1.47$ & 0.680 \\
\hline Richer & 1.33 & $0.82-2.16$ & 0.241 & 1.41 & $0.98-2.03$ & 0.068 & 1.35 & $0.97-1.88$ & 0.080 \\
\hline Richest & 1.85 & $1.11-3.1$ & 0.019 & 1.39 & $0.95-2.04$ & 0.094 & 1.91 & $1.35-2.69$ & $<0.001$ \\
\hline \multicolumn{10}{|l|}{ Occupation†† (Ref=Not Working) } \\
\hline Agriculture & 0.90 & $0.62-1.32$ & 0.604 & 0.82 & $0.65-1.04$ & 0.104 & 0.90 & $0.61-1.35$ & 0.623 \\
\hline Sales & 0.38 & $0.22-0.68$ & 0.001 & 1.05 & $0.79-1.41$ & 0.719 & 0.44 & $0.26-0.75$ & 0.002 \\
\hline Services and Others & 0.99 & $0.74-1.33$ & 0.952 & 0.83 & $0.67-1.02$ & 0.074 & 0.68 & $0.55-0.85$ & 0.001 \\
\hline
\end{tabular}

†Religion and ††Occupation were re-categorized

No widowed men participants were available in the three countries and divorced in Gabon

Table 2: Multivariate analysis showing associates of comprehensive HIVIAIDS knowledge among males of age 15-24 in the three countries.

Only Ivorian Christian males $(\mathrm{AOR}=1.49, p=0.031)$ were found to exhibit more comprehensive knowledge of HIV/AIDS compared to males with no religion. With regard to marital status, only Cameroonians living with partner were $(\mathrm{AOR}=0.63, p=0.011)$ less likely to have comprehensive knowledge than never in union. However, no association was found in Ivorian and Gabonese youth. Higher comprehensive knowledge of HIV/AIDS was found only in the richest wealth category group of males in Ivory Coast $(\mathrm{AOR}=1.85, p=0.019)$ and Gabon $(\mathrm{AOR}=1.91, p<0.001)$ as compared to the poorest. Sales in Ivory Coast $(\mathrm{AOR}=0.38, p=0.001)$ and Gabon $(\mathrm{AOR}=0.44, p=0.002)$ as well as services and others $(\mathrm{AOR}=0.68, p=0.001)$ in Gabon were less likely to have comprehensive knowledge of HIV/AIDS than males not working.

\section{Acceptance attitude of male youth}

The demographic variables like age in Ivory Coast, educational level and religion in all the three countries, marital status in Cameroon, wealth index in Cameroon and Gabon were found to be significant associates of acceptance attitude towards PLHA. Only in Gabon, males of 20-24 age group were $1.43(\mathrm{AOR}=1.43, p=0.005)$ times more likely to have higher acceptance attitude than males of 15-19 age group. However, no significant difference in acceptance attitude was found between urban and rural residents in the three countries.

An increase in odds ratio of acceptance attitude towards PLHA was observed in the three countries with increase in educational level. Significantly greater acceptance attitude was found in primary $(\mathrm{AOR}=1.60, p=0.027)$, secondary $(\mathrm{AOR}=3.56, p<0.001)$ and higher
$(\mathrm{AOR}=2.20, p=0.029)$ educational level than youth with no education in Ivory Coast. In Cameroon, only males with secondary $(\mathrm{AOR}=3.43$, $p=0.001)$ and higher $(\mathrm{AOR}=4.85, p<0.001)$ educational level had more acceptance attitude than males with no education. Similarly, males in primary $(\mathrm{AOR}=5.94, p=0.019)$, secondary $(\mathrm{AOR}=7.58, p=0.007)$ and higher $(\mathrm{AOR}=11.93, p=0.003$ ) educational level had more acceptance attitude than males with no education in Gabon.

Christian males in Ivory Coast $(\mathrm{AOR}=1.95, p=0.002)$ and Cameroon $(\mathrm{AOR}=2.28, p=0.013)$ as well as Muslim males (AOR=1.91, $p=0.026)$ in Gabon had higher acceptance attitude than males with no religion. With regards to marital status, Cameroonians living with partner $(\mathrm{AOR}=1.53, p=0.025)$ and those no longer living together $(\mathrm{AOR}=2.41$, $p=0.041$ ) have more acceptance attitude than males who were never in union. However, no significant results were found in Ivory Coast and Gabon. Males who work in agriculture had higher $(\mathrm{AOR}=1.62, p=0.032)$ acceptance attitude than those not working in Gabon. However, no significant association was found amongst occupation categories in both Ivory Coast and Cameroon.

The richest $(\mathrm{AOR}=1.64, p=0.011)$ in Gabon, as well as, poorer $(\mathrm{AOR}=1.72, p=0.019)$, middle $(\mathrm{AOR}=2.60, p<0.001)$, richer $(\mathrm{AOR}=2.51$, $p<0.001)$ and the richest $(\mathrm{AOR}=8.83, p<0.001)$ in Cameroon had higher acceptance attitude towards PLHA than the poorest. In Ivory Coast, none of the wealth index categories had significant acceptance attitude than the poorest. In Ivory Coast $(\mathrm{AOR}=1.47, p=0.002)$ and Cameroon $(\mathrm{AOR}=1.62, p<0.001)$, males with comprehensive knowledge were more likely to have higher acceptance attitude towards PLHA than 
Citation: Minet TH, Eyasu HT, Simon AG, Afewerki WT, Henok KA, et al. (2016) Associates of Comprehensive HIV/AIDS Knowledge and Acceptance Attitude among Male Youth Aged 15-24: Comparison Study among Ivory Coast, Cameroon and Gabon. J AIDS Clin Res 7: 618. doi:10.4172/2155-6113.1000618

Page 5 of 8

males with no comprehensive knowledge. In Gabon no significant association of acceptance attitude was found with comprehensive HIV/ AIDS knowledge.

\section{Comparison of comprehensive knowledge and acceptance attitude towards PLHA among the countries}

Comparison among the countries revealed no significant difference in comprehensive knowledge between Cameroonian and Gabonese male youth. However, Gabonese were 1.5 times more likely to have comprehensive HIV/AIDS knowledge than Ivorians (AOR=1.50, $p<0.001)$. On the other hand, Cameroonian were 1.44 times more likely to have comprehensive HIV/AIDS knowledge than those Ivorians $(\mathrm{OR}=1.44, p<0.001)$. Acceptance attitude towards PLHA among male youth of Ivory Coast was 1.18 times more than those in Gabon (AOR=0.85, $p=0.032$ ). Cameroonian male youth had 1.26 times more acceptance attitude than Gabonese youth (AOR=1.26, $p=0.001)$. However, no significant difference in acceptance attitude existed among Cameroonian and Ivorian male youth.

\section{Discussion}

\section{Comprehensive HIV/AIDS knowledge}

Having comprehensive HIV/AIDS knowledge is basic to implement a plan of HIV/AIDS prevention, care and support. The findings of this study revealed that awareness of HIV/AIDS in all the three countries was universal. Similar studies were also reported in Cameroon, subSaharan Africa and other countries [23-27]. However, comprehensive HIV/AIDS knowledge of male youth in the three countries was very low. This is far below target 3 set by UNAIDS in 2016 which states that $90 \%$ of young people regardless of where they live and who they are must have knowledge to protect themselves from HIV [2]. According to the recent research, $36 \%$ of young men in developing countries have comprehensive knowledge about prevention and transmission of HIV/ AIDS [10].

The older youth, 20-24 years, have more comprehensive HIV/ AIDS knowledge compared to their 15-19 aged counterparts in the three countries. Similarly, an increase of knowledge with advancing in age have been found in Botswana [28]. Similarly, urban residents were more likely to have higher comprehensive knowledge of HIV/AIDS compared to those living in rural among Gabonese youth. Similar results have also been reported from Sub Saharan Africa, Bolivia, India and Canada [29-33]. An urban and rural residence variation was found to be a considerable predictor of HIV/AIDS knowledge even after controlling other variables [33]. This could be of many reasons, for example the coverage of mass media and HIV/AIDS prevention programs in the urban could be more as compared to the rural which can widely influence the level of information and thereby determine the comprehensive knowledge of the residents $[30,34]$.

Significant positive association of comprehensive HIV/AIDS knowledge was observed with an increase in educational level of the respondents in all the three countries. This finding coincides with the studies done in Botswana, Ethiopia, and Ghana [24,28,29]. In the process of upgrading knowledge about HIV/AIDS, the sources of information, which can differ in their depth and accuracy, play an important role in adolescents. In a study done in Nigeria, more than 95\% of the adolescent students received information from school and others from mass media, newspapers, teachers, health workers, parents and family members, friends and class mates, TV shows and movies, and the internet. Of all the sources of information, school related information could be more structured and appropriate to age and level of understanding of the learners comparing to these mass medias like newspapers, TV, radio and the internet which broadcast information without specification to the general population. Similarly, other people like teachers, health workers, friends and class mates may share information but could not be deep and goal oriented to the extent that lesson plans and curriculums are designed to address the needs of the learners. Thus, being higher educated can have advantages over those with no education or low educational level. Another important dimension could be the educational level of parents and discussion about sexuality with parents [35]. In this case, having accurate and comprehensive HIV/AIDS knowledge of the parents can determine the knowledge of their youth. Besides, medium of dissemination of information can also influence the level of knowledge. For example, a study done in Ghana revealed that English as medium of disseminating information of the prevention strategies, directly affected for those with low or no education to comprehend the HIV/AIDS prevention strategies [36].

Christian males in Ivory Coast were more likely to have comprehensive knowledge of HIV/AIDS compared to males with no religion. This finding is congruent with results of the study from Botswana and Ethiopia, that reported significant association of religion with HIV/AIDS Knowledge [37,38]. The differences in the degree of HIV/AIDS knowledge among religions could be due to the fact that some churches might teach their followers about ways of preventing HIV/AIDS. On the hand, only Cameroonians living with their partner have more comprehensive HIV/AIDS knowledge than the unmarried youth.

The richest male youth in Ivory Coast and Gabon have significantly more comprehensive knowledge than the poorest male. This finding was supported by a study done in Ghana [24]. Similarly, in Ethiopia, family wealth index was found to be a strong associates of comprehensive HIV/AIDS knowledge among adolescents in which adolescents from a middle or high family wealth index were more likely to have comprehensive HIV/AIDS knowledge compared to those from a low family wealth index [39]. Studies indicated that, socioeconomic scarcities or lower wealth index could lead to low media exposure or lower levels of educational achievement which in turn affects HIV/ AIDS knowledge negatively [23,30]. Ivorian males working in sales had significantly higher comprehensive knowledge than those males not working. Similarly, Gabonese working in sales, services and others had also higher comprehensive knowledge than not working respondents. In this study, the level of comprehensive HIV/AIDS knowledge in different socio-economic groups of the three countries had been revealed in which it may help the policy makers to develop ways of education accordingly.

\section{Acceptance attitudes of male youth}

Having negative attitude towards PLHA is also another main obstacle for HIV/AIDS prevention among youth that brings about a big problem in developing care and support to wards PLHA [40]. In this study, acceptance attitude towards PLHA among male youth was generally low in all the three countries. Acceptance attitudes of individuals and populations towards PLHA can be attributed due to different manifestations of HIV/AIDS stigmas [41].

Male youth aged 20-24 had higher acceptance attitude towards PLHA than 15-19 age group in Ivory Coast. Similar results were found in other studies [29,42]. However, an increase in age does not always improve acceptance attitude [43]. With regard to place of residence, no significant difference in acceptance attitude was found between urban 
Citation: Minet TH, Eyasu HT, Simon AG, Afewerki WT, Henok KA, et al. (2016) Associates of Comprehensive HIV/AIDS Knowledge and Acceptance Attitude among Male Youth Aged 15-24: Comparison Study among Ivory Coast, Cameroon and Gabon. J AIDS Clin Res 7: 618. doi:10.4172/2155-6113.1000618

Page 6 of 8

and rural in the three countries. Similar results were found elsewhere [38,43]. However, other results have reported differently in Botswana, Ethiopia and Bolivia [31,37,44]. Educational level remarkably differentiates the acceptance attitude of youth. Likewise, in this study, a strong positive significant association was found between educational level and acceptance attitude towards PLHA in all the three countries. Other similar studies were reported from different regions of the world $[28,31,38,45,46]$.

In this study, religion in the three countries slightly affected their acceptance attitude. Christians from Ivory Coast and Cameroon as well as Muslim youth from Gabon have higher acceptance attitude than those with no religion. Similar study was found in Botswana, in which Christian youth had more positive attitudes towards PLHA than those who have no religion [28]. In the lives of the sub-Saharan Africans, religion plays a major role and has been recognized as a factor which may alleviate the HIV/AIDS stigma [47]. In a study done in Ethiopia, being religious and religious service attendant was found to be the highest significant factor where respondents who attend the religious service at least once a week were 7 times more likely to have favorable attitude than those who didn't attend the religious service [44].

With regards to marital status, only Cameroonian males living with partner and those no longer living together have more significant acceptance attitude than males who were never in union. However, no significant differences were found in Gabon and Ivory Coast. This is consistent with findings of other studies [43]. Related to wealth index, poorer, middle, richer and richest in Cameroon and only the richest in Gabon, had higher acceptance attitude than the poorest. Other researches also reported a positive significant association between wealth index and acceptance attitude [41,46]. Considering occupation only Gabonese males who work in agriculture had higher acceptance attitude than those not working. Having comprehensive HIV/AIDS knowledge showed significant association with acceptance attitude in Ivory Coast and Cameroon. Similar studies have been reported elsewhere $[28,38,43,46,48]$. Nevertheless, the comprehensive HIV/AIDS knowledge of the Gabonese youth was not statistically significantly associated with their acceptance attitudes. This indicates that knowledge alone is not enough for changing attitudes towards PLHA [49].

\section{Comparison among the countries}

Male youth in Gabon and Cameroon were almost one and half times more likely to have comprehensive HIV/AIDS knowledge than in Ivory Coast. This is congruent with the percentages of comprehensive knowledge of HIV/AIDS among Ivorian (39.1\%) and Gabonese (49.0\%) youth (Table 3). The main reasons for this might occur due to the literacy rate of male, the GDP per capita and the residential distribution of the people in the three countries. The large number of youth in Ivory Coast (27.2\%) with no education could be one reason. The lowest GDP per capita in Ivory Coast (1,600 USD), as compared to Cameroon (2,300USD) and Gabon (17,600USD) might be the second reason. Finally, the percent of urban population out of the total, was higher in Gabon (86.2\%) and

\begin{tabular}{|c|c|c|c|c|c|c|c|c|c|}
\hline \multirow[t]{2}{*}{ Variable } & \multicolumn{3}{|c|}{ Ivory Coast } & \multicolumn{3}{|c|}{ Cameroon } & \multicolumn{3}{|c|}{ Gabon } \\
\hline & OR & $95 \% \mathrm{Cl}$ & $\boldsymbol{P}$ & OR & $95 \% \mathrm{Cl}$ & $\boldsymbol{P}$ & OR & $95 \% \mathrm{Cl}$ & $\boldsymbol{P}$ \\
\hline \multicolumn{10}{|l|}{ Age (Ref=15-19) } \\
\hline $20-24$ & 1.06 & $0.87-1.29$ & 0.588 & 1.17 & $0.92-1.50$ & 0.200 & 1.43 & $1.11-1.84$ & 0.005 \\
\hline \multicolumn{10}{|l|}{ Place of Residence (Ref=Rural) } \\
\hline Urban & 0.92 & $0.71-1.19$ & 0.515 & 1.09 & $0.81-1.46$ & 0.588 & 1.09 & $0.73-1.62$ & 0.686 \\
\hline \multicolumn{10}{|c|}{ Highest Education level (Ref=No Education) } \\
\hline Primary & 1.89 & $0.88-4.05$ & 0.103 & 5.94 & $1.34-26.38$ & 0.019 & 1.60 & $1.05-2.42$ & 0.027 \\
\hline Secondary & 3.43 & $1.62-7.28$ & 0.001 & 7.58 & $1.74-33.10$ & 0.007 & 3.56 & $2.35-5.39$ & $<0.001$ \\
\hline Higher & 4.85 & $2.11-11.14$ & $<0.001$ & 11.93 & $2.37-60.22$ & 0.003 & 2.20 & $1.08-4.48$ & 0.029 \\
\hline \multicolumn{10}{|l|}{ Religion† (Ref=No religion) } \\
\hline Christian & 1.33 & $0.98-1.81$ & 0.067 & 3.11 & $1.38-7.02$ & 0.006 & 1.22 & $0.89-1.67$ & 0.209 \\
\hline Muslim & 1.34 & $0.98-1.83$ & 0.065 & 2.41 & $1.04-5.59$ & 0.041 & 1.57 & $0.92-2.69$ & 0.101 \\
\hline Other religion & 0.72 & $0.40-1.29$ & 0.272 & 1.70 & $0.62-4.72$ & 0.305 & 1.75 & $0.80-3.84$ & 0.163 \\
\hline \multicolumn{10}{|l|}{ Marital Status (Ref=Never in Union) } \\
\hline Married & 0.78 & $0.44-1.39$ & 0.398 & 1.01 & $0.27-3.85$ & 0.987 & 0.35 & $0.12-1.01$ & 0.052 \\
\hline Living with partner & 1.53 & $1.05-2.23$ & 0.025 & 0.87 & $0.57-1.34$ & 0.522 & 0.66 & $0.35-1.26$ & 0.206 \\
\hline Divorced & 2.68 & $0.29-24.95$ & 0.386 & & & & 0.00 & $0-0$ & 1.000 \\
\hline No longer living together/separated & 2.41 & $1.04-5.63$ & 0.041 & 1.03 & $0.45-2.34$ & 0.949 & 0.49 & $0.14-1.80$ & 0.285 \\
\hline \multicolumn{10}{|l|}{ Wealth Index (Ref=Poorest) } \\
\hline Poorer & 1.72 & $1.09-2.71$ & 0.019 & 1.16 & $0.84-1.61$ & 0.367 & 1.60 & $0.96-2.64$ & 0.069 \\
\hline Middle & 2.60 & $1.66-4.07$ & $<0.001$ & 1.40 & $0.96-2.03$ & 0.077 & 1.46 & $0.84-2.54$ & 0.176 \\
\hline Richer & 2.51 & $1.56-4.05$ & $<0.001$ & 1.41 & $0.96-2.08$ & 0.084 & 1.53 & $0.87-2.70$ & 0.143 \\
\hline Richest & 2.83 & $1.73-4.64$ & $<0.001$ & 1.64 & $1.12-2.40$ & 0.011 & 1.59 & $0.88-2.90$ & 0.125 \\
\hline \multicolumn{10}{|l|}{ Occupationt† (Ref=Not Working) } \\
\hline Agriculture & 1.72 & $1.09-2.71$ & 0.019 & 1.16 & $0.84-1.61$ & 0.367 & 1.60 & $0.96-2.64$ & 0.069 \\
\hline Sales & 2.60 & $1.66-4.07$ & $<0.001$ & 1.40 & $0.96-2.03$ & 0.077 & 1.46 & $0.84-2.54$ & 0.176 \\
\hline Services and Others & 2.51 & $1.56-4.05$ & $<0.001$ & 1.41 & $0.96-2.08$ & 0.084 & 1.53 & $0.87-2.70$ & 0.143 \\
\hline \multicolumn{10}{|c|}{ Comprehensive HIVIAIDS Knowledge (Ref=No) } \\
\hline Yes & & $1.34-1.94$ & $<0.001$ & 1.18 & $0.94-1.48$ & 0.1628 & 1.5 & $1.15-1.89$ & 0.0023 \\
\hline
\end{tabular}

†Religion and ††Occupation were re-categorized

Table 3: Multivariate analysis showing associates of acceptance attitude towards PLHA among males of age 15-24 in the three countries. 
Citation: Minet TH, Eyasu HT, Simon AG, Afewerki WT, Henok KA, et al. (2016) Associates of Comprehensive HIV/AIDS Knowledge and Acceptance Attitude among Male Youth Aged 15-24: Comparison Study among Ivory Coast, Cameroon and Gabon. J AIDS Clin Res 7: 618. doi:10.4172/2155-6113.1000618

Page 7 of 8

\begin{tabular}{|l|c|c|c|c|c|c|c|}
\hline Country & \multirow{2}{*}{ Reference } & \multicolumn{4}{|c|}{ Comprehensive Knowledge } & \multicolumn{3}{|c|}{ Acceptance Attitude } \\
\cline { 3 - 8 } & & OR & $\mathbf{9 5 \% C l}$ & $\mathbf{P}$ & $\mathbf{O R}$ & $\mathbf{9 5 \%} \mathbf{C l}$ & $\mathbf{P}$ \\
\hline Gabon & Ivory Coast & 1.50 & $1.31-1.71$ & $<0.001$ & 0.85 & $0.73-0.99$ & 0.032 \\
\hline Cameroon & Ivory Coast & 1.44 & $1.28-1.63$ & $<0.001$ & 1.07 & $0.93-1.22$ & 0.354 \\
\hline Cameroon & Gabon & 0.96 & $0.85-1.08$ & 0.536 & 1.26 & $1.10-1.45$ & 0.001 \\
\hline
\end{tabular}

Table 4: Comparison of comprehensive HIVIAIDS knowledge and acceptance attitude towards PLHA among the three countries.

Cameroon (52.1\%) than Ivory Coast (51.3\%) (Table 4) [50-52]. Even though no significant difference in acceptance attitude existed among Cameroonian and Ivorian male youth, Gabonese had significantly less acceptance attitude than Ivorians. Other studies have also shown that a high level of knowledge might not always reflect an individual's attitudes but rather acceptance attitude might be influenced by counseling, coping skills acquisition, increased access to drugs, empathy for PLHA through direct contact [53].

\section{Conclusion}

The study highlighted shortage of comprehensive HIV/AIDS knowledge among youth. This comprehensive knowledge was significantly associated with age, residence, educational level, and wealth index. It is suggested to improve comprehensive knowledge in adolescents, rural areas, teenage individuals, and people having lower wealth index through sexual health education and prevention programs to reverse some of the knowledge gaps and correct the misconceptions.

On the other hand, the lack of acceptance attitude and its association with age, religion, educational level, and wealth index suggests that specific and focused educational programs that can empower the citizens to adopt positive attitudes and safe sexual behavior to prevent HIV transmission early in life is crucial. Looking over the comparisons among the three countries, even though there existed significant difference, focus and actions to improve comprehensive knowledge and acceptance attitude are quite important. A future study of the sexual behavior of these youth is suggested to plan effective policy of care, support and prevention to tackle HIV transmissions.

\section{Strength and Limitations}

The facts that the sample was large and nationally representative selected by probability proportional to size were the strengths of the study. Defining the dependent variables based on the MEASURE DHS online tools for HIV/AIDS Survey Indicators Database is also another significant strength of the research which is an internationally-accepted and consistent method for measuring factors related to HIV prevention across countries.

The findings in this study are not only highlighting the existing gap in knowledge and acceptance attitude but also could guide the policy makers to plan effective policy of health education to scale-up awareness of HIV/AIDS of the youth. However, the self-report nature of the study might have an effect in recall bias, socially-desirable responses and under-reporting. Besides, the cross-sectional nature of the study can only help us to see the associations but not cause and effect. Thirdly, the unexpected large missing data in Cameroon might affect the results in the analysis.

\section{Acknowledgement}

We would like to thank the Demography and Health Surveys (DHS) Program, ICF International Rockville USA, for allowing us to use the raw data for this study.

\section{References}

1. UNAIDS (2015) World AIDS day: Fact sheet 2015.

2. UNAIDS (2016) On the fast-track to end AIDS

3. United States Agency for International (2012) HIV/AIDS health profile: SubSaharan Africa.

4. L'Institut National de la S, ICF International (2012) HIV prevalence in Cameroon: Finding from the 2011 DHS-MICS.

5. UNAIDS (2014) HIV and AIDS estimates: Cameroon.

6. La Direction Générale de la S, ICF International (2013) Prévalence du VIH/sida au Gabon: Résultats de l'EDSG-II 2012.

7. UNAIDS (2014) HIV and AIDS estimates: Gabon.

8. Institut National de la S, ICF International (2013) Prévalence du VIH en Côte d'Ivoire: Résultats de l'EDS-MICS 2011-2012.

9. UNAIDS (2014) HIV and AIDS Estimates: Côte d'Ivoire.

10. UNAIDS (2012) Fact sheet on adolescents, young people and HIV/AIDS.

11. Christane NA (2014) HIVIAIDS prevalence, knowledge, attitudes and related behaviors among young people in Libreville, Gabon. IOSR Journal of Humanities and Social Science 19: 59-65.

12. Aichele SR, Borgerhoff MM, James S, Grimm K (2014) Attitudinal and behavioral characteristics predict high risk sexual activity in rural Tanzanian youth. PLoS One 9: e99987.

13. Anne LS (2013) Global action to reduce HIV stigma and discrimination: Supplement 2. Journal of the International AIDS Society 16: 3.

14. Sales JM, Milhausen RR, Diclemente RJ (2006) A decade in review: building on the experiences of past adolescent STI/HIV interventions to optimise future prevention efforts. Sexually transmitted infections 82: 431-436.

15. Oladepo O, Fayemi MM (2011) Perceptions about sexual abstinence and knowledge of HIVIAIDS prevention among in-school adolescents in a western Nigerian city. BMC Public Health 11: 304.

16. Jacobi CA, Atanga PN, Bin LK, Mbome VN, Akam W, et al. (2013) HIVIAIDS related stigma felt by people living with HIV from Buea, Cameroon. AIDS Care 25: $173-180$.

17. Tarkang EE (2009) Knowledge, attitudes and perceptions regarding HIV/AIDS and sexual behaviours among senior secondary school learners in Kumba, Cameroon. UNISA.

18. Kongnyuy EJ, Wiysonge CS, Mbu RE, Nana P, Kouam L (2006) Wealth and sexual behaviour among men in Cameroon. BMC Int Health Hum Rights 6: 11

19. Kongnyuy EJ, Wiysonge CS (2007) Alcohol use and extramarital sex among men in Cameroon. BMC Int Health Hum Rights 7: 6 .

20. UNAIDS (2010) UNAIDS report on the global AIDS epidemic 2010.

21. DHS (2016) The DHS Program, demographic and health surveys. USAID.

22. DHS (2016) Measure DHS online tools. HIVIAIDS Survey Indicators Database

23. Tsala DZ, Kuate DB (2011) Fostering accurate HIV/AIDS knowledge among unmarried youths in Cameroon: Do family environment and peers matter? BMC Public Health 11: 348.

24. Nketiah AE, Afful MG (2013) A review of HIVIAIDS awareness and knowledge of preventive methods in Ghana. Afr J Reprod Health 17: 69-82.

25. Amoako AKN (2012) Adolescent religiosity and attitudes to HIV and AIDS in Ghana. SAHARA J 9: 227-241.

26. Deribew A, Abebe G, Apers L, Jira C, Tesfaye M, et al. (2010) Prejudice and misconceptions about tuberculosis and HIV in rural and urban communities in Ethiopia: A challenge for the TB/HIV control program. BMC Public Health 10 400 .

27. Hansson M, Stockfelt L, Urazalin M, Ahlm C, Andersson R (2008) HIVIAIDS awareness and risk behavior among students in Semey, Kazakhstan: A crosssectional survey. BMC Int Health Hum Rights 8: 14.

28. Majelantle RG, Keetile M, Bainame K, Nkawana P (2014) Knowledge, opinions and attitudes towards HIV and AIDS among Youth in Botswana. Journal of Global Economics. 
Citation: Minet TH, Eyasu HT, Simon AG, Afewerki WT, Henok KA, et al. (2016) Associates of Comprehensive HIV/AIDS Knowledge and Acceptance Attitude among Male Youth Aged 15-24: Comparison Study among Ivory Coast, Cameroon and Gabon. J AIDS Clin Res 7: 618. doi:10.4172/2155-6113.1000618

29. Mulu W, Bayeh A, Mulat $Y$ (2014) Knowledge, attitude and practices on HIVIAIDS among students of Bahir Dar University. Science Journal of Public Health 2: 78-86.

30. Akininola B, Susheele S, Vanessa W, Deirdre W (2004) Risk and protection: Youth and HIVIAIDS in sub-Saharan Africa.

31. Terán CC, Gorena UD, González BC, Alejos FB, Ramírez RO, et al. (2015) Knowledge, attitudes and practices on HIVIAIDS and prevalence of HIV in the general population of Sucre, Bolivia. The Brazilian journal of infectious diseases 19: 369-375.

32. Hazarika I (2010) Knowledge, attitude, beliefs and practices in HIVIAIDS in India: Identifying the gender and rural-urban differences. Asian Pacific Journal of Tropical Medicine 3: 821-827.

33. Veinot TC, Harris R (2011) Talking about, knowing about HIVIAIDS in Canada: A rural-urban comparison. J Rural Health 27: 310-318.

34. Ciampa PJ, Skinner SL, Patricio SR, Rothman RL, Vermund SH, et al. (2012) Comprehensive knowledge of HIV among women in rural Mozambique: Development and validation of the HIV knowledge 27 scale. PLoS One 7: e48676.

35. Adeleke IT, Bilkisu AA, Danjuma A, Lateef MO, Abdulkarim S. (2015) HIV/AIDS awareness among secondary schools adolescents in south-western Nigeria: A correlate to strengthen advocacy and strategic sexuality education programs. American Journal of Health Research 3: 61-67.

36. Sallar AM (2009) Correlates of misperceptions in HIV knowledge and attitude towards people living with HIVIAIDS (PLWHAs) among in-school and out-ofschool adolescents in Ghana. Afr Health Sci 9: 82-91.

37. Majelantle RG, Keetile M, Bainame K, Nkawana P (2014) Knowledge, opinions and attitudes towards HIV and AIDS among Youth in Botswana. Journal of Global Economics 2: 3-7.

38. Mulu W, B Abera, M Yimer (2014) Knowledge, attitude and practices on HIVI AIDS among students of Bahir Dar University. Sci J Pub Health 2: 78-86.

39. Oljira L, Berhane Y, Worku A (2013) Assessment of comprehensive HIV/AIDS knowledge level among in-school adolescents in eastern Ethiopia. J Int AIDS Soc 16: 17349

40. IvoryCoast (2014) rapport national de la cote D'Ivoire 2014
41. Terán CC, Gorena UD, González BC, Alejos FB, Ramírez RO, et al. (2015) Knowledge, attitudes and practices on HIVIAIDS and prevalence of HIV in the general population of Sucre, Bolivia. Braz J Infect Dis 19: 369-375.

42. Okudo J (2012) Knowledge and attitudes of young people in Nigeria about HIV/ AIDS- A systematic review.

43. Rahnama R, Rampal L, Lye MS, Rahman HA (2011) Factors influencing students' attitude towards HIVIAIDS in a Public University, Malaysia. Global Journal of Health Sci 3: 128-135.

44. Regassa N, Kedir S (2011) Attitudes and practices on HIV preventions among students of higher education institutions in Ethiopia: The case of Addis Ababa University. East African Journal of Public Health 8: 141-154.

45. Madiba S, Mokgatle MM (2014) HIV and AIDS related knowledge and attitudes towards learners infected with HIV: Survey among high school learners in Gauteng and North West provinces in South Africa. Peer J 693: 2-28.

46. Tacaids Z, Ocgs I (2013) HIVIAIDS and malaria indicator survey 2011-12, Tanzania. Dar es Salaam, Tanzania: Tanzania 103-110.

47. Mbonu NC, Vanden BB, De Vries NK (2009) A model for understanding the relationship between stigma and healthcare-seeking behavior among people living with HIVIAIDS in sub-Saharan Africa. African Journal of AIDS Research 8: 201-212.

48. Megabiaw B, Awoke T (2013) Comprehensive knowledge, attitude and practice of street adults towards human immunodeficiency virus/acquired immune deficiency syndrome (HIVIAIDS) in Northwest Ethiopia 5: 181-187.

49. Shiferaw Y, Alemu A, Girma P, Getahun A, Kassa A, et al. (2011) Assessment of knowledge, attitude and risk behaviors towards HIVIAIDS and other sexual transmitted infection among preparatory students of Gondar town, north west Ethiopia. BMC Research Notes 4: 505.

50. Cameroon (2015) Factbook, Index Mundi.

51. Gabon (2015) Factbook, Index Mundi.

52. d'Ivoire C (2015) Factbook, Index Mundi.

53. Brown L, Macintyre K, Trujillo L (2003) Interventions to reduce HIVIAIDS stigma: What have we learned? AIDS Educ Prev 15: 49-69. 